\title{
Prevalence of common poultry diseases in chicken and influence of different medicinal herbs on the growth of broiler chicken
}

\author{
Ahmed Ali Moryani ${ }^{1}$, Nasir Rajput ${ }^{*}$, Muhammad Naeem Rajput ${ }^{2}$ and \\ Atta Hussain Shah ${ }^{3}$ \\ 1. Department of Poultry Husbandry, Sindh Agriculture University, Tando Jam-Pakistan \\ 2. Department of Livestock Management, Sindh Agriculture University, Tando Jam-Pakistan \\ 3. Department of Animal Products Technology, Sindh Agriculture University, Tando Jam-Pakistan \\ *Corresponding author's email: drnasirrajput@yahoo.com \\ Citation \\ Ahmed Ali Moryani, Nasir Rajput, Muhammad Naeem Rajput and Atta Hussain Shah Prevalence of common \\ poultry diseases in chicken and influence of different medicinal herbs on the growth of broiler chicken. Pure and \\ Applied Biology. Vol. 9, Issue 1, pp1199-1208. http://dx.doi.org/10.19045/bspab.2020.90126
}

Received: $14 / 11 / 2019 \quad$ Revised: $21 / 01 / 2020$

Accepted: $27 / 01 / 2020$

Online First: 07/02/2020

\section{Abstract}

Current study was designed to explore common poultry diseases in broiler and layer chicken at farm level in different areas of Sindh, Pakistan and to observe the growth performance of broiler supplemented with medicinal herbs. Pre-tested questionnaire was used to interview various poultry farmers and information about common health problems in broiler and layer were identified. The common diseases of broiler at farm level were E.coli (81\%), IBD (69\%), CRD (67\%), infectious bronchitis (13\%), mycotoxins (5\%), salmonelosis (4\%), Newcastle disease (3\%) and Cocci (2\%). While in layers occurrence of cholera $(60 \%)$, avian influenza (45\%), E.coli (12\%), mycotoxins (10\%), IB (8\%), CRD (5\%), Marek's (5\%), New castle disease (4\%), salmonelosis (2\%) and Hydro Pericardium Syndrome (2\%) were identified. Birds in group-C, D \& G supplemented with Giloy/Satgullo, Tabashir \& Gadamri/Imli consumed more fed (3040, $3000 \& 3000 \mathrm{~g} /$ bird) than group-B, F \& E (2980, 2948 \& 2871g/ bird) fed with Aloe vera, Hing/Vaghayani \& Anwara herbs and against control group-A (2770g/bird). The FCR values of group-F, E, G, C \& D (1.40, 1.45, 1.47, 1.50 and 1.50) fed with Hing/Vaghayani, Anwara, Gadamri/Imli, Tabashir \& Giloy herbs were statistically lower against group-A (1.70) and groupB (1.62). Considerably high live body weight was noted in group-F (2100g/bird) supplemented with Hing/Vaghayani followed by group-G, C, D \& E (2060, 2050, 2020, 1990 \& 1750g/ bird) supplemented with Gadamri/Imli, Giloy/Satgullo, Tabashir, Anwara \& Aloe vera medicinal herbs compared to control; group-A (1647g/bird) fed on basal diet.

Keywords: Body weight; Broiler; FCR; Feed intake; Medicinal herbs; Pakistan

Introduction

Being a sub-sector of the agriculture of Pakistan, the contribution of the poultry in the gross domestic production of the country is $1.3 \%$, though it is considered as one the most vital and lively section of the 
agriculture. Currently $>700$ billion rupees are the investment worth of the sector and it grows rapidly with the rate of 8 to $10 \%$ per year over last few years back [1]. According to the present statistical figures, in term of largest poultry producers of the world, Pakistan is existed at $11^{\text {th }}$ number and country produces 1,163 million broilers annually. This sector provides large number of opportunities for public employment and over 1.5 million people are engaged in the poultry business. It is also a cheapest source of protein against beef and mutton because of their high prices [2]. In the total meat production of the country $(4,478 ; 000$ tons $)$ share of the poultry meat is $34 \%(1,518$; 000tons). In contrast to last three years in the years of 2018-19 the growth trend of poultry meat and egg production is increases up to 9.1 and $5.6 \%$, respectively whereas egg production [3]. With the passage of time poultry industry facing many disasters, especially due to various health problems like cholera, salmonelosis, new castle disease, E.coli infection, coccidiosis, especially in early 1990s Hydro Pericardium Syndrome was diagnosed and severely damaged the broiler and broiler breeder flocks. In addition, in 1991 broiler, layer and parent flocks were badly affected by the infectious bursal disease. Still the industry was trying to adjust itself from the earlier damage produced due to Hydro Pericardium Syndrome and Infectious Bursal disease attacks in poultry, in 1994 outbreak of another contagious health problem in shape of Avian Influenza caused $80 \%$ mortality in the parent flocks at Murree and Abbotabad cities of Pakistan [4, 5]. It was cited that during last five decades with the addition of allopathic growth promoters with different brands of antibiotics the productive and growth performance of poultry especially in broiler, it improved with a great extent. But in the present scenario the consensus of the society around the world is diverting to the community safety concerns, instead of productive efficiency. After alarming the antibiotic resistance problem as a major health problem by the World Health Organization (WHO) at world level, the brim of the research is elicited to discover appropriate non-hazardous substitute for allopathic antibiotics [6]. Being a substitute of allopathic medication, plant herbs and their byproducts consists of their extracts and essential oils are used as dietary supplements for the meat production of broiler and their influential as phytogenic feed additives in to the poultry diet [7]. These medicinal plants increase productive performance of poultry and health generally by stabilizing the microorganisms of intestine inhabiting the growth of pathogenic microbes and improving the performance and production of digestive enzymes [8]. The most common herbs and plant extracts which are used as an alternative source of antimicrobials in poultry are aloe vera, giloy, tabasheer, vaghayani, anwara, gadamri, garlic, cumin, black cumin, wild mint, pumpkin, thyme, cinnamon, chestnut, clove, alfalfa, turmeric, sumac, mushroom, grape seed, goldthread, mulberry leaf and honeysuckle [9]. Among all these medicinal herbs each and every plant or their extracts and essential oils consists of many bioactive chemical compounds which can be used as growth promoter, diuretic, anthelmintic, appetizer, alkaline phosphates stimulator, antibacterial and antifungal agent $[10,11]$. Keeping in view the significance of herbal plants in terms of growth promotion and disease prevention efficiency and scarce knowledge about the subject in the Sindh province of Pakistan, study has been designed to document various herbal plants and their effect on the productive performance of broiler chicken. 


\section{Materials and methods}

\section{Location of study}

Present research work was conducted in two phases, under phase-I a preliminary investigation was carried out at different vicinities of Sindh province for the prevalence of common diseases in layer and broiler chickens at different poultry farms. Under phase-II, after collection of questionnaire data experimental trial was conducted at the Department of Poultry Husbandry, Faculty of Animal Husbandry and Veterinary Sciences, Sindh Agriculture University Tandojam.

Prevalence of common poultry diseases at broiler and layer farms

A Survey was conducted at different vicinities of the Sindh province for recording the prevalence of common diseases in broiler and layer chickens farms. For this purpose a uniform pre-tested questionnaire was used to interview from poultry farmers/dealers of Sindh.

\section{Medicinal herbs/plants}

All the medicinal herbs (Aloe vera, Giloy/Satgullo, Tabashir, Anwara, Hing/Vaghayani and Gadamri/Imli) were purchased from the locality of the study area and brought to the Poultry Husbandry department for further processing.

\section{Experimental design}

A research trial was carried out to check the impact of medicinal plants on the growth performance of broiler at Poultry Husbandry Department, Faculty of Animal Husbandry and Veterinary Sciences, Sindh Agriculture University Tandojam. A total of 350 day-old broiler chicks were purchased from well reputed broiler Breeder Company and divided into seven groups, each group comprises fifty $(n=50)$ birds. All the allocated groups of birds were treated with similar diet (starter and finisher) along with six (6) medicinal plants supplemented in water.

Among all seven groups, group-A was kept as control (fed on free antibiotic and antifungal basal diet), while group B was supplemented with Aloe vera followed by group C (Giloy/Stagullo), group D (Tabashir), group E (Anwara), group F (Hing/Vaghayani), while group $\mathrm{G}$ of birds was supplemented with Gadamri/Imli. The dosage form and detail of medicinal herbs is given in (Table1).

Table 1. Medicinal herbs used during the experimental trial with their dosage form

\begin{tabular}{|c|l|l|l|l|c|}
\hline S.No. & Local name & \multicolumn{1}{|c|}{ Botanical name } & \multicolumn{1}{c|}{ Part used } & \multicolumn{1}{c|}{ Dosage } & Source \\
\hline 1. & Aloe vera & Aloe barbadensis & Leave juice & $5 \mathrm{ml} / \mathrm{litter}$ & Drinking water \\
\hline 2. & Giloy/Satgullo & Tinaspora Cordifolia & Stem & $12 \mathrm{~g} / \mathrm{litter}$ & Drinking water \\
\hline 3. & Tabashir & Bambusa arundinacea & Siliceous secretion & $3 \mathrm{~g} / \mathrm{litter}$ & Drinking water \\
\hline 4. & Anwara & Emblica officinalis & Fruit & $5 \mathrm{~g} / \mathrm{litter}$ & Drinking water \\
\hline 5. & Hing/Vaghyani & Ferula foetida regel & Gum resin & $500 \mathrm{mg} /$ litter & Drinking water \\
\hline 6. & Gadamri/Imli & Tamarindus indica & Fruit pulp & $25 \mathrm{~g} / \mathrm{litter}$ & Drinking water \\
\hline
\end{tabular}

\section{Feeding and management}

Crumble feed was provided twice a day at morning and evening, and water was offered ad libitum throughout the trial. Total feed and water consumption was recorded on daily basis. The feed was formulated according to the recommendation of National Research Council (NRC) [12]. Table 2 shown the composition and constituents present in basal diet. Well ventilated sheds, litter material and uniform management measures were taken for the bird allocated in different groups. The medicinal herb supplementation was given with prescribed doses in the clean water to the birds from day first up to the end of the experimental trial. Starter feed was provided from day first to $21^{\text {st }}$ day and grower feed was offered from day $22^{\text {nd }}$ to $38^{\text {th }}$ day of the experiment. 


\section{Feed conversion ratio (FCR)}

The FCR value was calculated by dividing the consumed feed by live body weight using following formula.
$\mathrm{FCR}=\underline{\text { Average feed intake }(\mathrm{g})}$ Average live body weight $(\mathrm{g})$

Table 2. Feed ingredients and composition of basal diets for broiler

\begin{tabular}{|c|c|c|}
\hline Ingredients (\%) & Starter diet & Finisher diet \\
\hline Rice & 60.25 & 65.47 \\
\hline Soybean meal & 32.5 & 28 \\
\hline Corn gluten meal & 3 & 2.5 \\
\hline Lime stone & 1.2 & 1.2 \\
\hline DCP & 2 & 1.8 \\
\hline Sodium Chloride & 0.3 & 0.3 \\
\hline Feed premix ${ }^{1}$ & 0.5 & 0.5 \\
\hline L- lysine & 0.1 & 0.1 \\
\hline Dl- methionine & 0.15 & 0.13 \\
\hline \multicolumn{3}{|c|}{} \\
\hline ME (kcal/kg) & Chemical composition \\
\hline CP \% & 2998 & 3023.9 \\
\hline Lysine \% & 21.19 & 19.20 \\
\hline Methionine \% & 1.21 & 1.09 \\
\hline Ca \% & 0.496 & 0.440 \\
\hline P \% & 0.988 & 0.949 \\
\hline \multicolumn{2}{|c|}{}
\end{tabular}

\section{Live body weight}

Analytical weighing balance was used for calculating the live body weight of birds. Weekly body weight was recorded in the morning. While at the end of the experimental trial (38 days) the final body weight of the birds was also recorded.

\section{Data analysis}

The collected data was tabulated on the excel sheet and analyzed through Student Edition of Statistix (SXW) software, Version 8.1 statistical package. For the verification of significant differences among the variables of the data analysis of variance (ANOVA) was applied in case of significant differences exist; the least significant difference (LSD) value at $5 \%$ level of probability was applied on the obtained means values.

\section{Results and discussion}

Prevalence of common diseases at broiler and layer farms

In the current investigation during the preliminary survey, interviews were conducted with the help of uniform pretested questionnaire from various poultry farmers/dealers about the common diseases in broilers and layers facing by poultry farmers at farm level at different vicinities of Sindh province (Figures $1 \& 2$ ). In the current investigation at broiler chicken farms the maximum prevalence of E.coli $(81 \%)$ was recorded, followed by Infectious bursal disease (69\%), Chronic respiratory disease (67\%), Infectious bronchitis (13\%), Mycotoxins (5\%), Salmonelosis (4\%), Newcastle disease $(3 \%)$ and Cocci $(2 \%)$ disease. While at layer farms the occurrence of Cholera (60\%) disease was found high compared to that of Avian Influenza (45\%), E.coli (12), Mycotoxins (10\%), IB (8\%), CRD (5\%), Marek's (5\%), New castle disease (4\%), Salmonelosis (2\%) and Hydro Pericardium Syndrome (2\%) disease at different vicinities of Sindh province. Similar findings are reported by Hussain $e t$ al. [1] they found that the broiler and layer 
poultry farms were severely affected by various poultry disease. In continuation Akhtar et al. [4] recoded evidences of Hydro Pericardium Syndrome in poultry caused heavy losses to broiler chicken and their breeder flocks. Similarly, the prevalence of Gumboro disease adversely effected broiler, layer and parent flocks. Furthermore the poultry industry was just trying to recover the earlier damage of Hydro Pericardium Syndrome and infectious bursal disease outbreak, the occurrence of Avian Influenza in Abbotabad and Murree was reported in the parental flocks with $80 \%$ mortality of birds [4, 5]. A panel of scientists reported 42.1\% Fowl Coryza, 50.5\% fowl typhoid and $100 \%$ prevalence of Marek's disease in broiler and layer chickens. These problems severely affected the poultry sector of the country [13]. According to Food and Agriculture organization figures reported in 2011 the first outbreak of Avian influenza at different poultry farms of Pakistan was occurred in 1995, when highly pathogenic avian influenza serotype $\mathrm{H} 7 \mathrm{~N} 3$ was diagnosed in commercial breeding stocks resulted in decrease egg production and increase in mortality [14].

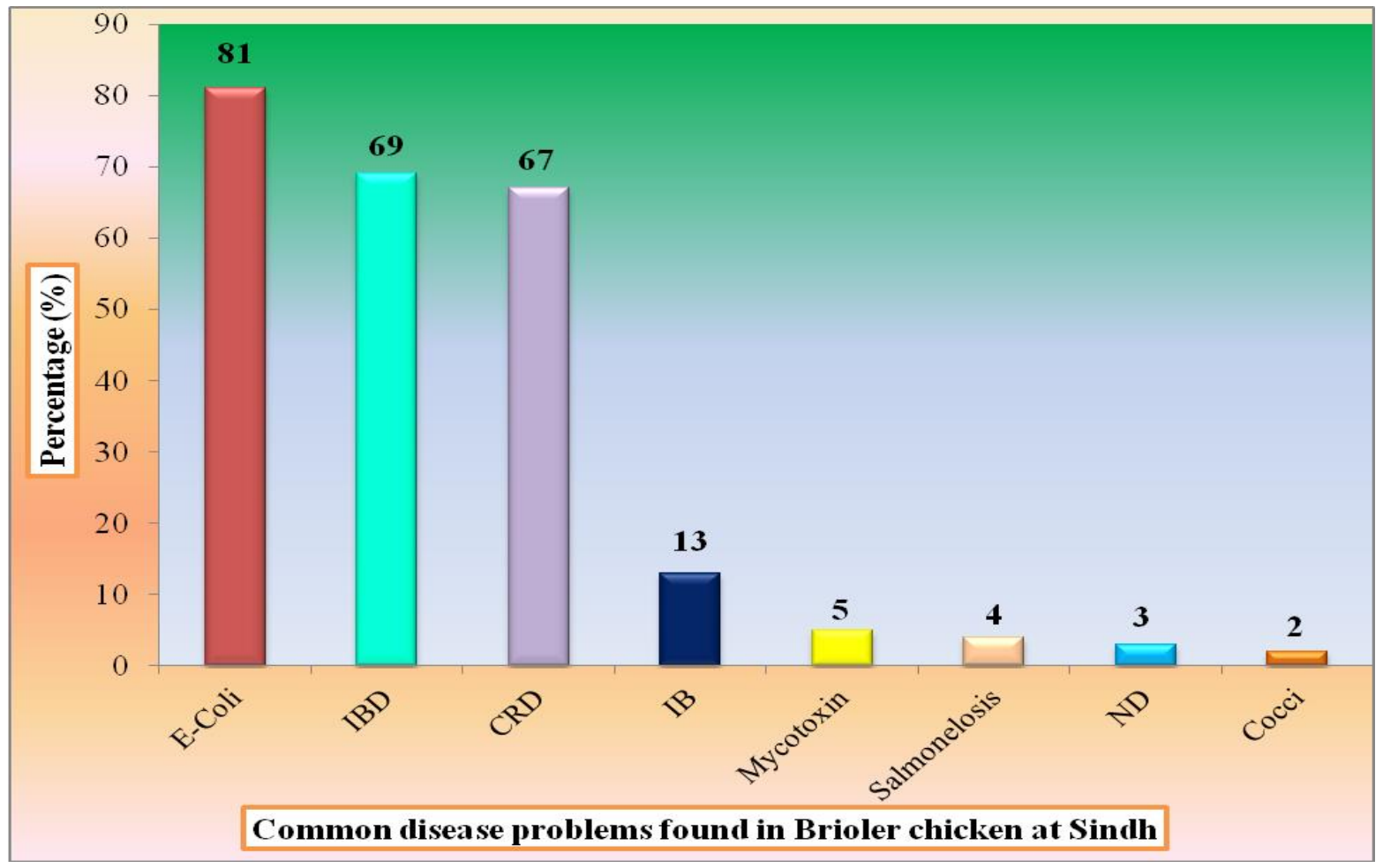

Figure 1. Prevalence of common poultry diseases at broiler chicken farm 


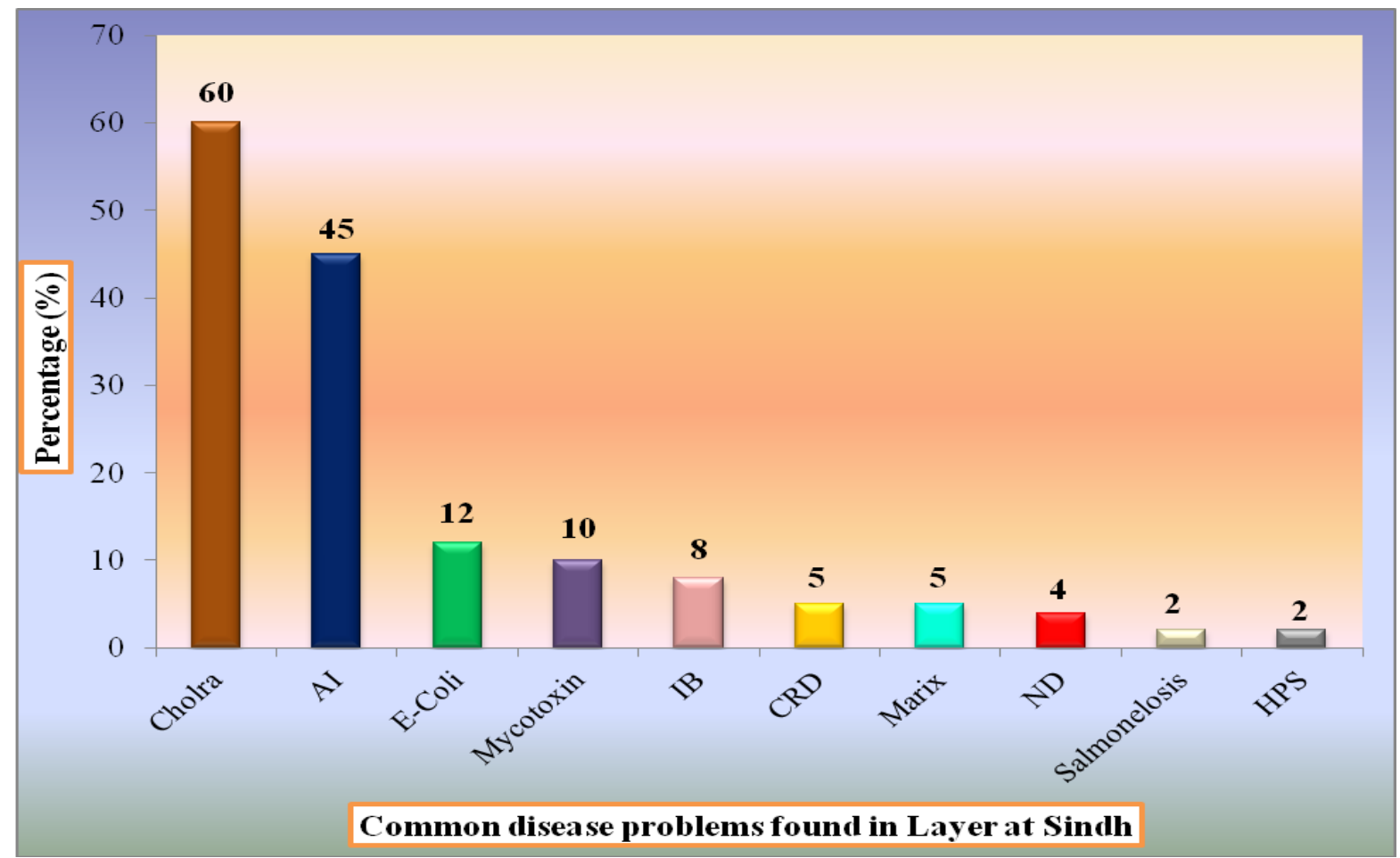

Figure 2. Prevalence of common poultry diseases at layer chicken farm

\section{Feed intake}

The interactive influences of different medicinal plants on feed intake of broiler chickens were recorded against control and results are depicted in (Figure 3). Significantly $(\mathrm{P}<0.05)$ high feed intake was recorded in boiler supplemented with Giloy/Satgullo, Tabashir and Gadamri/Imli group (3040, 3000 and $3000 \mathrm{~g} / \mathrm{bird}$, respectively) compared to birds supplemented with Aloe vera, Hing/Vaghayani and Anwara (2980, 2948 and $2871 \mathrm{~g} / \mathrm{bird}$, respectively), while minimum feed intake was recorded in control $(2770 \mathrm{~g} / \mathrm{bird})$. In accordance with current study, dietary addition of herbs with therapeutic properties increased feed consumption and decrease FCR and regulate normal function of digestion in broiler, which indicated that the natural products have beneficial photochemical which can improve the biological development of chicken [9]. Significant influence of native herbal plants; Withania somnifera, Asparagus racemosus and Mucuna pruriens were recorded on the feed intake of broiler chickens [15]. Similarly, ziziphora, oregano and peppermint are dietary medicinal plants; significantly increase the feed intake of broiler chicken [16]. Alike, medicinal herbs like, Anacardium occidental, Psidium guajava and Morinda citrifolia were used by different researchers to enhance the feed consumption and production level of the broiler chickens [17, 18].

\section{Feed conversion ratio}

The results regarding feed conversion ratio (FCR) showed that better FCR was observed in broiler supplemented with Hing/Vaghayani (1.40), followed by birds supplemented with Anwara (1.45), Gadamri/Imli (1.47), Tabashir (1.50) and Giloy/Satgullo (1.50) herbs, respectively. While, poor FCR value was recorded in birds (1.62) supplemented with Aloe vera and control (1.70) group (Figure 4). In line with current results the addition of chicory 
root powder in feed improved FCR of poultry birds compared to control [19]. In another study it was cited that the use of Aloe vera increased the body weight, feed efficiency and decreased the FCR. These herbs used as anticoccidial agents, reduce the mortality rate, cost of feed, fat accumulation and enhance carcass weight, liver, spleen and giblet weight in broiler chicken $[20,21]$. In addition the use of medicinal herbs and plant extracts in the diets of broiler improved the FCR values and increased weight gain and carcass yield $[22,23]$.

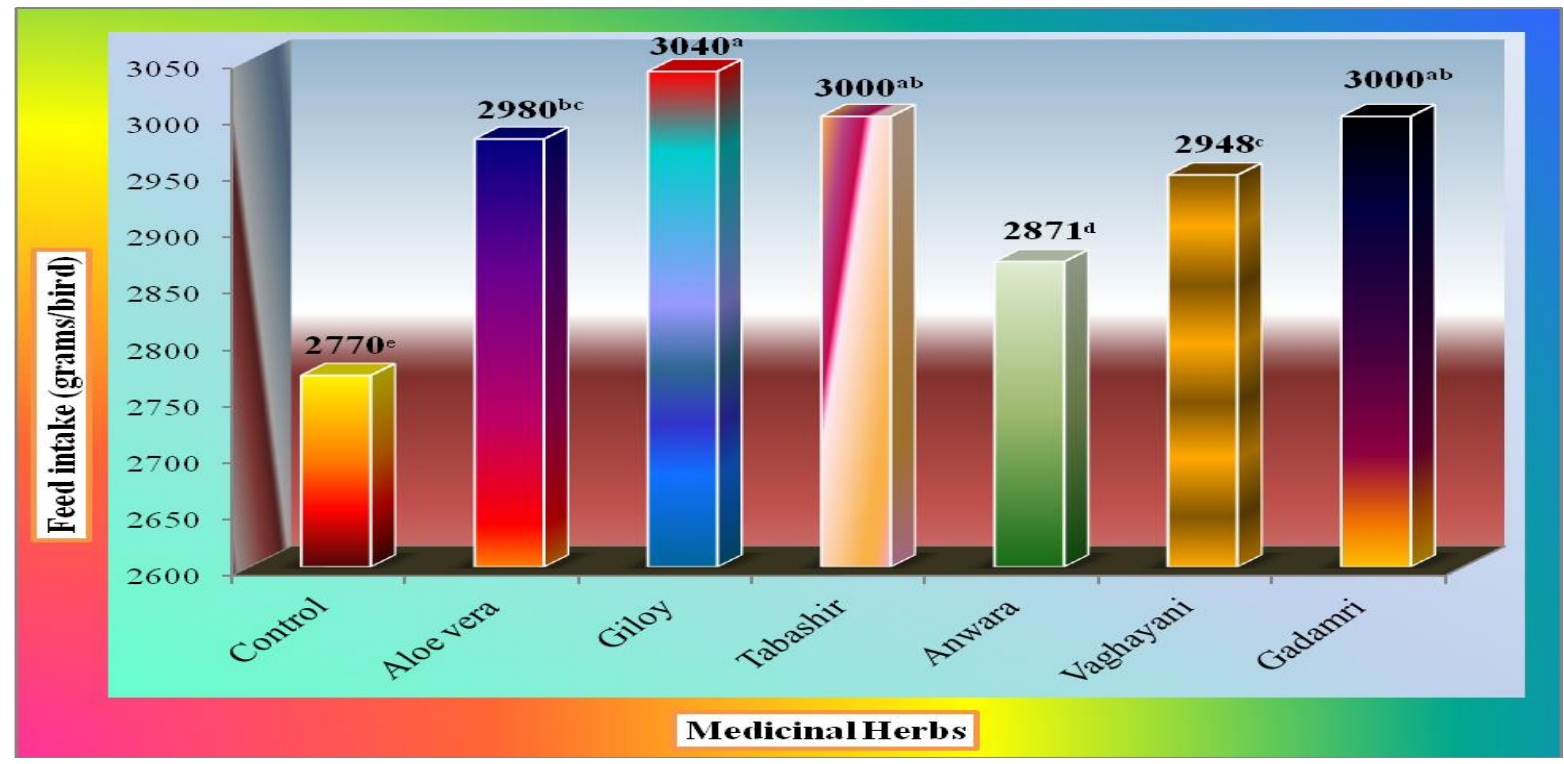

Figure 3. Influence of different medicinal herbs on the feed intake of broiler chicken. $P$ value $=0.043$

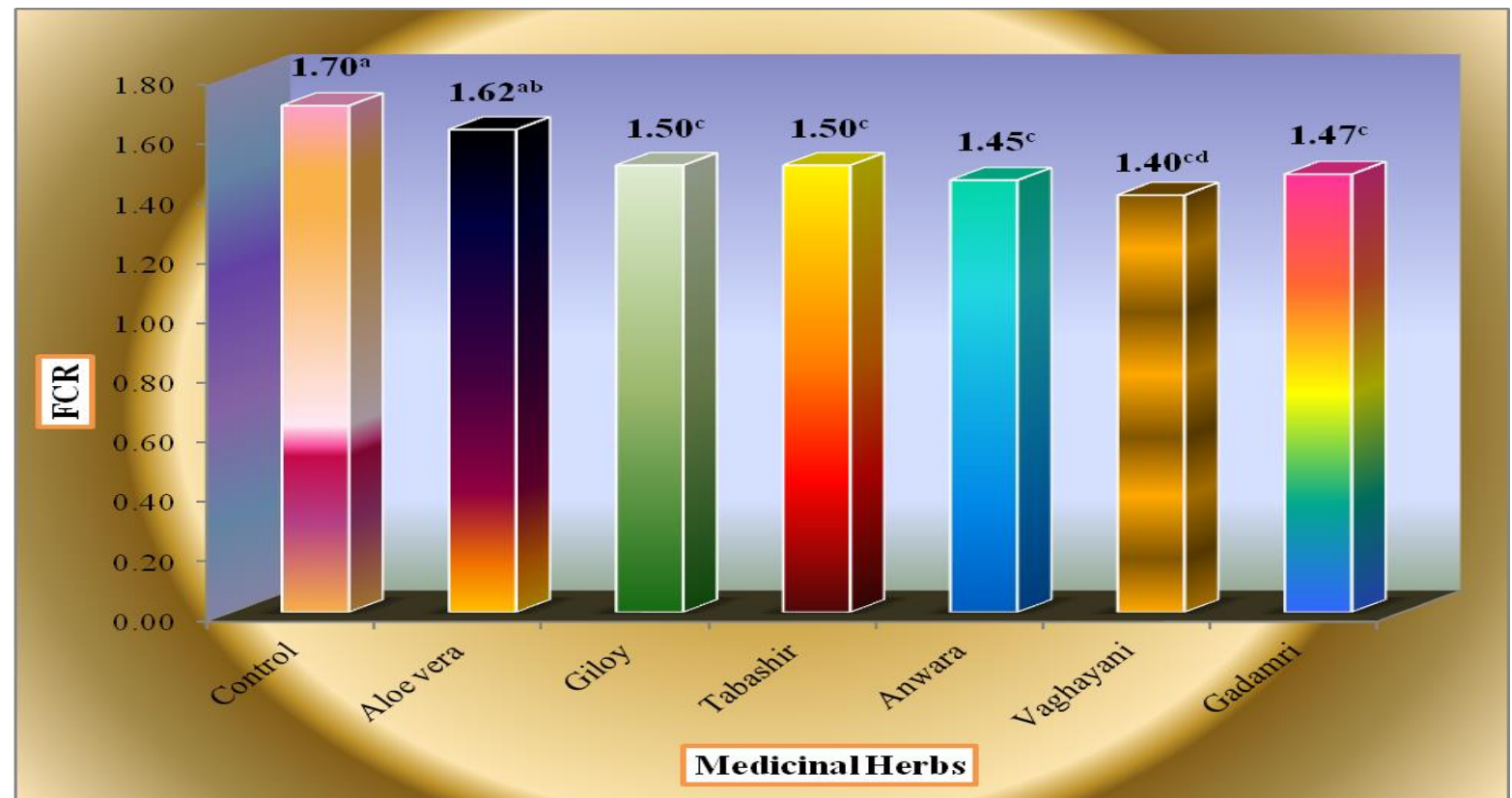

Figure 4. Influence of different medicinal herbs on the FCR of broiler chicken. $P$ value $=0.045$ 


\section{Live body weight}

The results regarding the live body weight showed that significantly higher live body weight $(2100 \mathrm{~g} / \mathrm{bird})$ was noted in broiler supplemented with Hing/Vaghayani followed by birds supplemented with Gadamri/Imli, Giloy/Satgullo, Tabashir and Anwara (2060, 2050, 2020 and 1990g $\mathrm{g} /$ bird, respectively) herbs compared to birds supplemented with Aloe vera (1750 g/bird) and control group (1647g/bird) against rest of all herb supplemented groups of birds (Figure 5). Similar findings were reported by Buchanan et al [23] reported that minimum FCR and increased body weight of birds was observed in birds fed medicinal plant extracts along with basal diet. Similarly, Ajwain herb supplementation with regular diet improved body weight of broiler chicken than birds fed on control diet [24]. Contradictory, Aloe vera has significant therapeutic against coccidiosis, but it was not considered as a good growth promoter compared with other medicinal plants. Moreover, the significant improvement was observed in the body weight of broiler chicken fed on different growth promoters; medicinal plants compared to birds fed on basal diet [25].

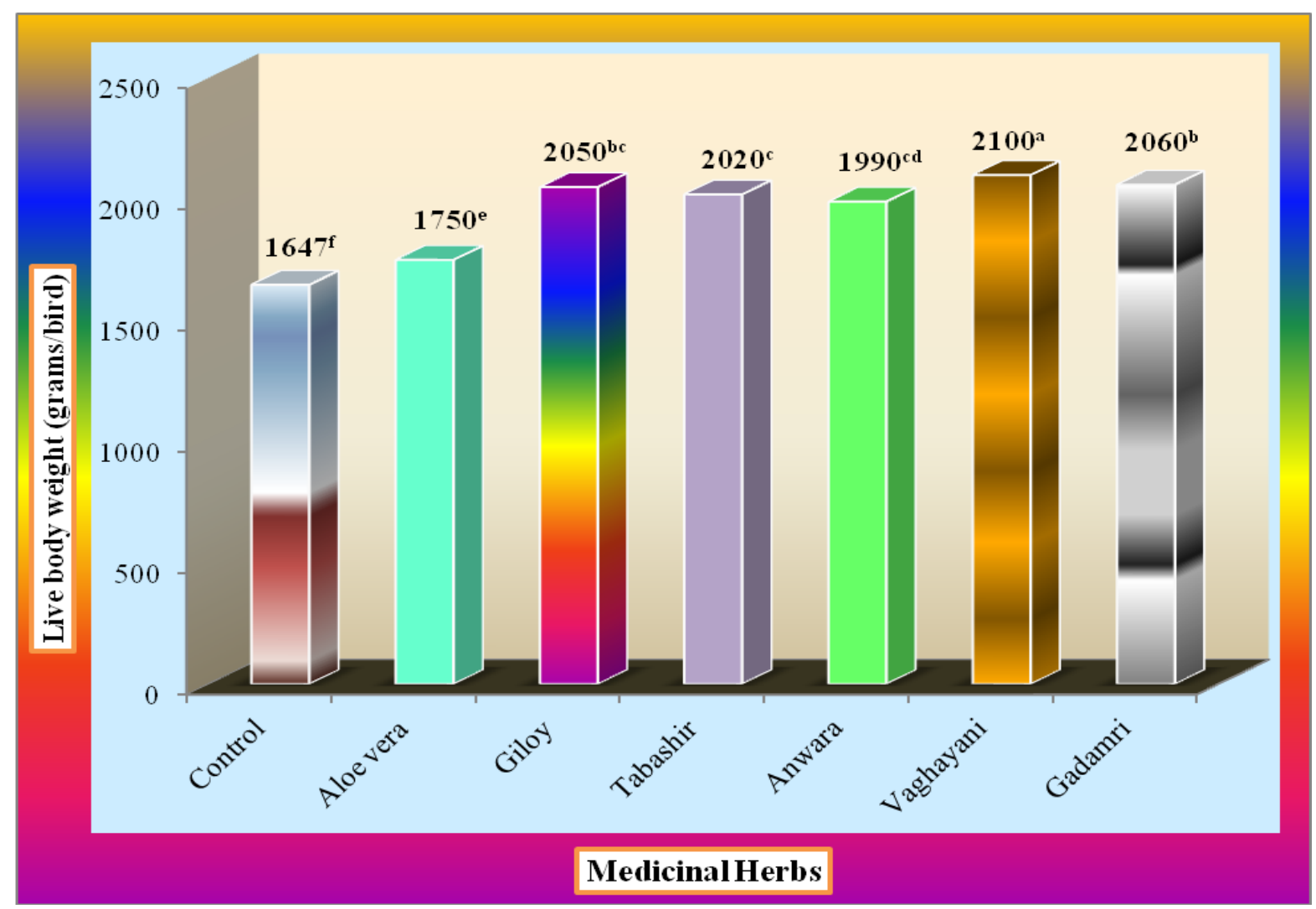

Figure 5. Influence of different medicinal herbs on live body weight of broiler chicken. $\mathbf{P}=\mathbf{0 . 0 3 8}$

\section{Conclusions}

It has been concluded that the most prevalent diseases like; E.coli, IBD, CRD in broiler while, Cholera and Avian Influenza in layer adversely affects the poultry farms at different vicinities of the Sindh, Pakistan. Medicinal plants/herbs might be used as good alternative source of costly allopathic 
therapeutic agents and growth promoters. Medicinal plants like, Hing/Vaghayani, Gadamri/Imli, Giloy/Satgullo, Tabashir, Anwara and Aloe vera supplementation was produced significantly better effects on the feed intake, FCR and live body weight of broiler chicken.

\section{Author's contributions}

Conceived and designed the experiments: AA Moryani \& N Rajput, Performed the experiments: AA Moryani, Analyzed the data: M Naeem, Contributed reagents/ materials/ analysis tools: N Rajput \& AH Shah, Wrote the paper: N Rajput \& AA Moryani.

\section{Acknowledgement}

We are very much grateful to Birds Care Research \& Diagnostic Centre Tandojam, for providing financial \& technical support of study.

\section{References}

1. Hussain J, Rabbani I, Aslam S \& Ahmad HA (2015). An overview of poultry industry in Pakistan. Worlds Poult Sci J 71(4): 689-700.

2. GOP (2018-19). Pakistan Economic survey Economic Adviser's Wing, Finance Division Government of Pakistan, Islamabad.

3. Farooque A (2019). Agriculture: Livestock and Poultry sectors. Economic Adviser's Wing, Finance Division Government of Pakistan, Islamabad, pp 11-34.

4. Akhtar S (1994). Hydro-pericardium Syndrome in broiler chicken in Pakistan. World's Poult Sci J 50(2): 177-182.

5. Anjum AD, Sabri GS \& Jamshidi, K (1994). Occurrence spread and control of infectious bursal disease in Pakistan. Proceedings of 1st PPA-PVMA Punjab, Inter Poult Conf 57-59.

6. Soltan MA, Shewita RS \& El-Katcha MI (2008). Effect of dietary anise seeds supplementation on growth performance, immune response, carcass traits and some blood parameters of broiler chickens. Inter J Poult Sci (7): 10781088.

7. Dalkilic B \& Guler T (2009). The Effects of clove extract supplementation on performance and digestibility of Nutrients in broilers. F U Sag Bil Vet Derg (23): 161-166.

8. Tekeli A, Elik L, Kutlu HR \& Grgulu M (2006). Effect of dietary supplemental plant extracts on performance, carcass characteristics, digestive system development, intestinal microflora and some blood parameters of broiler chicks. Abstract Book of $12^{\text {th }}$ Eur Poult Conf, Verona- Italy 10-14 ${ }^{\text {th }}$ Sept.2006.

9. Aroche R, Yordan M , Zheng R , Guiping G, Samuel W, Charles M, Dairon M \& Shile L (2018). Dietary Inclusion of a Mixed Powder of Medicinal Plant Leaves Enhances the Feed Efficiency and Immune Function in Broiler Chickens. J Chem 1-7.

10. Hajati H, Ahmad $\mathrm{H}$ \& Frahang A (2014). Application of Medicinal Plants in Poultry Nutrition. $J$ Med Plants and By-products (1): 1-12.

11. Smith CF (2001). The use of herbs in treating diseases of commercial poultry. Paper presented in Gatton Poultry Symposium., Deptt: Anim Stud UQ Gatton.pp. 4343.

12. National Research Council, 1994. Nutrient Requirements of Poultry. 9th rev. ed. National Academy Press, Washington, DC.

13. Mwale M, Evison B, Michael C \& Tinyiko EH (2005). Use of Herbal Plants in Poultry Health Management in the Mushagashe Small-Scale Commercial Farming Area in Zimbabwe. Inter J Appl Res Vet Med 3(2): 163-170.

14. FAO (2011). Pakistan and Food and Agriculture Organization. Achievements and success stories. FAO representation in Pakistan. GOP (Government of 
Pakistan) (2013) Federal Bureau of Statistics, Ministry of Finance, Government of Pakistan.

15. Srivastava SB, Singh DP, Ram N \& Paswan VK (2012). Effect of herbal drugs as a feed additive in broiler ration. The Bioscan 7(2): 267-269.

16. Rad MN, Nobakht A, Shahryar HA, Kamani J \& Lotfil A. (2011). Influence of dietary supplemented medicinal plants mixture (Ziziphora, Oregano and Peppermint) on performance and carcass characterization of broiler chickens. $J$ Med Plants Res 5(23): 5626-5629.

17. Bampidis VA, Christodoulou V, FlorouPanei P, Christaki E, Chatzopoulou PS, Tsiligianni T \& Spais AB (2005). Effect of dietary dried oregano leaves on growth performance, carcass characteristics and serum cholesterol of female early maturing turkeys. British Poult Sci (46): 595-601.

18. Aghazadeh AM \& Nabiyar E (2015). The effect of chicory root powder on growth performance and some blood parameters of broilers fed wheat-based diets. J Appl Anim Res 43(4): 384-389.

19. Griggs JP \& Jacob JP (2005). Alternatives to antibiotics for organic poultry production. J Appl Poult Res (14): 750-756.

20. Hassan SM (2013). Effects of guar meal, guar gum and saponin rich guar meal extract on productive performance of starter broiler chicks. J Agri Res 8(21): 2464-2469.

21. Salami SA, Majoka MA, Saha S, Garber A \& Gabarrou JF (2015). "Efficacy of dietary antioxidants on broiler oxidative stress, performance and meat quality: science and market." Avian Biol Res 8(2): 65-78.

22. Buchanan NP, Hott JM, Cutlip SE, Rack AL, Asamer A \& Moritz JS (2008). "+e effects of a natural antibiotic alternative and a natural growth promoter feed additive on broiler performance and carcass quality." J Appl Poult Res 17(2): 202-210.

23. Valiollahi M, Gholami R, Namjoo M, Rahimian AR \& Rafiee A (2014). Effect of using Sumac (Rheus coriaria L.) \& Ajwain (Trachyspermum ammi) powders on performance and intestinal microbial population in broiler chicks. Res Vet Sci 4(10): 545-549.

24. Omar JA, Hejazi A \& Badran R (2016). Performance of Broilers Supplemented with Natural Herb Extract. Open J Anim Sci (5): 68-74.

25. Khaligh F, Ghorbanali S, Ahmad K \& Asaad V (2011). Evaluation of different medicinal plants blends in diets for broiler chickens. J Med Plants Res 5(10): 1971-1977. 